\title{
Hypolipidemic, Hypoglycemic and Antioxidant Activities of Flower Extracts of Allamanda violacea A.DC. (Apocynaceae)
}

\author{
Arun Sethi $^{{ }^{\star}}$, Rohit Prakash ${ }^{1}$, Akriti Bhatia ${ }^{1}$, Gitika Bhatia ${ }^{2}$, Ashok K \\ Khanna $^{2}$ and Swayam Prakash Srivastava ${ }^{2}$ \\ ${ }^{1}$ Department of Chemistry, University of Lucknow, Lucknow-226007, ${ }^{2}$ Division of Biochemistry, Central Drug \\ Research Institute, Lucknow, India.
}

\begin{abstract}
Purpose: To investigate the anti-dyslipidemic, anti-oxidant and anti-diabetic activities of the aqueous extract and solvent fractions of $A$. violacea flowers.

Methods: The aqueous extract was fractionated into petroleum ether, ether, chloroform, chloroformmethanol (4:1) and chloroform-methanol (3:2) fractions. Lipid lowering activity was evaluated in two models, viz, triton WR-1339 - induced hyperlipimea in rats as well as fructose-rich high fat diet. To assess anti-oxidant activity, in-vitro model of non-enzymic superoxide hydroxyl radicals and microsomal lipid peroxidation by non-enzymic inducer was adopted. Hypoglycemic activity was evaluated by sucrose-loaded rat model.

Results: Amongst the fractions, ether and chloroform fractions caused marked decrease in the levels of total cholesterol (TC), triglycerides (Tg), plasma lipids (PI), and protein by 24, 23, 23 and $22 \%$, and 24, 22, 23 and $19 \%$, respectively. In rats fed with high fat diet (HFD), ether and chloroform fractions lowered Tc, Tg and, Pl by 26, 25 and $26 \%$, and 18, 19 and $20 \%$, respectively. Significant decrease in superoxide anions, hydroxyl radicals and microsomal lipid peroxidation by ether and chloroform fractions was also observed. Chloroform, chloroform-methanol (4:1) and chloroform-methanol (3:2) fractions showed antihyperglycaemic activity to the extent of 25.2, 21.6 and $23.2 \%$, respectively.

Conclusion: The flowers of this plant, especially the ether and chloroform extracts, may be suitable for anti-oxidant use and lipid management.
\end{abstract}

Keywords: Allamanda violacea flowers, Anti-hyperlipidemic, Anti-hyperglycemic, Anti-oxidant. 


\section{INTRODUCTION}

Atherosclerosis is the major cause of heart diseases, stroke and death in both developed and developing countries. It is well established that elevated levels of low density lipoproteins constitute primary risk factors for atherosclerosis. Epidemiological studies have indicated that dyslipidemia and coagulation disturbances are among the most significant risk factor for the development of atherosclerotic conditions [1]

Current pharmacological treatment of atherosclerosis includes the use of the statin class of 3-hydroxy-3-methyl glutaryl.CoA (HMG.CoA) reductase inhibitors and the fibrate class, peroxisome proliferatoractivated receptor alpha (PPARa) antagonists. They are effective in lowering triglyceride $(\mathrm{Tg})$ and low density lipoprotein (LDL) but most patients still experience coronary events despite statin therapy. In addition, reports of undesirable side effects (myopathy) of some 'super statins' in which the scope of improving the potency of this class of drug may be modest [2]. Furthermore, the fibrate class of drugs, which are mostly used to treat hypertriglyceridemia and low HDL cholesterol, requires high doses to show significant efficacy [3]. In addition, a combination of fibrate and statin has met with serious safety concerns as exemplified by the withdrawal of cerivastatin in 2001. Besides, hyperglycemia and dyslipidemia, which are the two major components of metabolic syndrome, are also one of the crucial risk factors for cardiovascular diseases [4]. Therefore, there is a need for a different class of compounds to treat hyperglycemia and dyslipidemia without the attendant serious side effects.

Oxidative stress has recently been implicated in the pathogenesis of various diseases such as diabetes and coronary artery diseases. Hydroxyl free radical $(\mathrm{OH})$ has also been found to be responsible for the peroxidative damage to lipoproteins present in the blood, which in turn are responsible for the initiation and progression of atherosclerosis [5]. Therefore, treating both oxidative stress and disorders of lipid metabolism together, may be a novel approach to regress atherosclerosis and other cardiovascular diseases. We reported earlier that some precursors in hormone synthesis, such as, guggulsterone, possess lipid-lowering activity, together with mild anti-oxidant effect and also inhibit oxidative modification of LDL [6]. Recently, we also found that some pregnane derivatives exhibited antioxidant and anti-dyslipidemic activities simultaneously $[7,8]$.

A. violacea (purple allamanda, violet allamanda, syn A. blanchetti) is an ornamental plant of Allamanda genus in the Apocyanaceae family. Previous phytochemical examination of this plant indicated the presence of plumericin, isoplumericin and 5, 6-dimethoxycoumarin [9]. The ethanol extracts of the roots, leaves and stems of this plant have been reported to posses' cytostatic and cytotoxic activities [10]. However, no work has been reported on the flowers of this plant. The present study was undertaken to evaluate the anti-dyslipidemic, anti-oxidant and anti-diabetic activities of the extract and fractions of the flowers of $A$. violacea.

\section{EXPERIMENTAL}

\section{Chemicals and reagents}

All the chemicals/solvents used were of high purity (AR/GR grade) and all the solvents used were dried by standard procedures. Triton WR-1339 was purchased from Sigma Chemical Company, St Louis, MO, USA and high fat diet (HFD) from Research Diet Inc, New Brunswick, USA (Product code no. D 99122211). TG test kits and total cholesterol test kits were purchased from Merck Co.

\section{Preparation of extract}

The whole plant of $A$. violaceae was collected in the month of October 2010 from Lucknow, 
India. The identity of the plant was confirmed by Dr Tariq Hussain, Head, Department of Taxonomy and Herbarium, National Botanical Research Institute, Lucknow, India, where a voucher specimen, no. 97108, was deposited.

The flowers of the plant were shade-dried, powdered, soaked in water overnight and exhaustively extracted by percolation with ethanol of increasing concentration from 50 to $95 \%$ at room temperature [11]. The combined alcoholic extract was concentrated in a rotator evaporator under reduced pressure to get the hydroalcohol extract. The hydroalcohol extract was shaken successively with petroleum ether $\left(\mathrm{Pet}_{\mathrm{Et}} \mathrm{O}\right.$, $\left.35{ }^{\circ} \mathrm{C}, 1000 \mathrm{ml} \times 3\right)$, ether $\left(\mathrm{Et}_{2} \mathrm{O}, 1000 \mathrm{ml} \times 3\right)$, chloroform $\left(\mathrm{CHCl}_{3}, 1000 \mathrm{ml} \times 3\right)$, chloroform: methanol $\left(\mathrm{CHCl}_{3}: \mathrm{CH}_{3} \mathrm{OH}, 4: 1,1000 \mathrm{ml} \times 3\right)$, chloroform: methanol $\left(\mathrm{CHCl}_{3}: \mathrm{CH}_{3} \mathrm{OH}, 3: 2\right.$, $1000 \mathrm{ml} \mathrm{x3}$ ) for preliminary separation of the constituents of different polarities. The fractionation was carried out at room temperature and the organic layer was removed from the separating funnel only when there was a separation of a clear layer. After fractionation was complete, the residue was discarded.

\section{Phytochemical screening of extract fractions}

The extract fractions were subjected to phytochemical tests for carbohydrates and/or glycosides, tannins, flavonoids, and sterols and/or terpenes.

\section{Chromatographic analysis}

High performance liquid chromatography (HPLC) analyses was carried out on a Waters HPLC system, equipped with Waters 717 plus auto sampler, Waters 2998 photodiode array detector (PDA), using Column aquasil C-18 (250 mm × $4.6 \mathrm{~mm})$. The results were analysed by Empower 2 software, Build 2154. Samples were eluted in a linear gradient of water and acetonitrile. $(80: 20, v / v)$ as the mobile phase. Flow rate was constantly kept at $0.8 \mathrm{ml} / \mathrm{min}$. The UV spectrum of the petroleum ether, ether and chloroform fractions showed absorption bands in the range of $200.8-322.2 \mathrm{~nm}$, 200.8 - $375.6 \mathrm{~nm}$ and 212.5 - $294.9 \mathrm{~nm}$, respectively, corroborating the presence of flavonoids/sterols/terpenes in these extracts $[12,13]$. The chloroform-methanol $(4: 1)$ and chloroform-methanol (3:2) showed absorption bands in the range 257.2 - 293.8 and 256.0 $260.7 \mathrm{~nm}$, respectively, indicating the absence of steroids/triterpnoids and flavonoids and possibly, phenolic compounds.

\section{Experimental animals}

Rats (Charles Foster strain, male, adult, body weight $200-225 \mathrm{~g}$ ) were kept in a room with controlled temperature $\left(25-26{ }^{\circ} \mathrm{C}\right)$, humidity $(60-80 \%)$ and $12 / 12 \mathrm{~h}$ light/dark cycle (light on from 8.00 a.m to 8.00 p.m) under hygienic conditions. Animals, which were acclimatized for one week before starting the experiment, had free access to normal diet and water ad libitum $[7,8]$.

Central Drug Research Institute Animal Ethics Committee approved the animal studies (approval ref no. 120/10/ Biochem/IAEC) which also followed Committee for the Purpose of Control and Supervision on Experiments on Animals (CPCSEA) guidelines as well as those of GLP Annual Welfare Board, Government of India.

\section{Assessment of triton- and cholesterol- induced hyperlipidemia}

The rats were divided into nine treatment groups of six rats each, namely, control, triton-induced, triton + hydroalcohol extract, triton + petroleum ether fraction, triton + ether fraction, triton + chloroform fraction, triton + chloroform:methanol (4:1) fraction, triton + chloroform: methanol (3:2) fraction and triton + drug (gemfibrozil, $100 \mathrm{mg} / \mathrm{kg}$ ). Hyperlipidemia was developed over an 18 hour period by administration of triton WR- 
1339 (Sigma, St. Louis, MO, USA) at a dose of $400 \mathrm{mg} / \mathrm{kg}$ intraperitoneally to all the animals except control. Fractions/extracts were triturated with $0.2 \% \mathrm{w} / \mathrm{v}$ aqueous gum acacia suspension and fed orally $(100 \mathrm{mg} / \mathrm{kg}$ ) and simultaneously with triton, and further feeding was stopped. Animals in the control and triton groups, which did not receive fraction/extract treatment, received the same amount of gum acacia suspension (vehicle). After $18 \mathrm{~h}$ of treatment, the animals were anaesthetized with thiopentone solution (50 $\mathrm{mg} / \mathrm{kg}$ ) prepared in normal saline and then 2 $\mathrm{mL}$ blood was withdrawn from retro-orbital sinus using glass capillary in EDTA-coated Eppendorf tube (3 $\mathrm{mg} / \mathrm{ml}$ blood). The blood was centrifuged at $2500 \mathrm{~g}$ and $4{ }^{\circ} \mathrm{C}$ for 10 $\mathrm{min}$ to separate plasma. The plasma was diluted with normal saline (1:3) and used for analysis of total cholesterol (Tc), triglycerides (Tg) and phospholipids (PI) by standard enzymatic methods [14].

In the chronic experiment, hyperlipemia was produced by feeding with high fat diet (HFD) once a day for 30 days. The fraction/extract was administered $(50 \mathrm{mg} / \mathrm{kg})$ orally simultaneously with HFD to the extracttreated groups. The control animals received the same amount of normal saline $(2.5 \mathrm{ml} / \mathrm{kg})$ or arachis oil $(5 \mathrm{ml} / \mathrm{kg})$. At the end of the experiment, the rats were fasted overnight and blood $(2 \mathrm{~mL})$ was withdrawn. The animals were killed and their liver promptly excised. The plasma was analyzed for Tc, $\mathrm{Tg}, \quad \mathrm{PI}$ and lecithin: cholesterol acyltransferase activity (LCAT) and postheparin lipase activity (PHLA) activity.

\section{Assessment of antioxidant activity}

Generation of free radicals: Superoxide anions $\left(\mathrm{O}^{-2}\right)$ were generated enzymatically [14] by xanthine $(160 \mathrm{mM})$, xanthine oxidase $(0.04 \mathrm{U})$ and nitroblue tetrazolium $(320 \mu \mathrm{M})$ in absence or presence of petroleum ether, ether, chloroform, chloroform-methanol (4:1) and chloroform: methanol (3:2) fractions/ extracts $(400 \mu \mathrm{g} / \mathrm{ml})$ in $100 \mathrm{mM}$ phosphate buffer ( $\mathrm{pH}$ 8.2). Fractions were sonicated well in phosphate buffer before use. The reaction mixtures were incubated at $37{ }^{\circ} \mathrm{C}$ and after $30 \mathrm{~min}$, the reaction was stopped by adding $0.5 \mathrm{~mL}$ glacial acid. The amount of formazone formed was measured at $560 \mathrm{~nm}$ on a spectrophotometer. Inhibition (\%) was calculated by taking the absorption coefficient of formazone as $7.2 \times 10^{3} \mathrm{M}^{-1} \mathrm{~cm}^{-1}$.

In another set of experiments, the effect of petroleum ether, ether, chloroform, chloroform-methanol (4:1) and chloroform: methanol (3:2) fractions/extracts on the generation of hydroxyl radicals $(\mathrm{OH})$ was studied by non-enzymic reactants [14]. Briefly $\mathrm{OH}$ was generated in a non-enzymic system comprised of deoxyribose (2.8 $\mathrm{mM})$, $\mathrm{FeSO}_{4} .7 \mathrm{H}_{2} \mathrm{O}(2 \mathrm{mM})$, sodium ascorbate $(2.0$ $\mathrm{mM}$ ) and $\mathrm{H}_{2} \mathrm{O}_{2}(2.8 \mathrm{mM})$ in $50 \mathrm{mM} \mathrm{KH_{2 }} \mathrm{PO}_{4}$ buffer $(\mathrm{pH} \mathrm{7.4)}$ to a final volume of $2.5 \mathrm{~mL}$. The reaction mixtures above, in the absence or presence of the fractions/extracts (400 $\mu \mathrm{g} / \mathrm{ml}$ ) were incubated at $37^{\circ} \mathrm{C}$ for $90 \mathrm{~min}$. Reference tubes and reagent blanks were also run simultaneously. Malondialdehyde (MDA) content in both experimental and reference tubes were estimated spectrophotometrically by thiobarbituric acid method as stated above [14].

\section{Assessment of antihyperglycaemic activity}

Male albino rats of Charles Foster strain with mean body weight of $160 \pm 20 \mathrm{~g}$ were selected for this study. The blood glucose level of each animal was checked with the help of glucometer (Boehringer Mannheim) after $16 \mathrm{~h}$ starvation. The animals showing blood glucose level between 3.33 and 4.44 $\mathrm{mM}(60-80 \mathrm{mg} / \mathrm{dl})$ were divided into eight groups of five animals each. The test group was administered a suspension of the extract orally (formulated in $1 \%$ gum acacia) at a dose of $100 \mathrm{mg} / \mathrm{kg}$ while the control group received an equal amount of $1 \%$ gum acacia $(400 \mu \mathrm{l})$ only. A sucrose load $(10 \mathrm{~g} / \mathrm{kg})$ was given to each animal of both groups orally 30 min later, to evaluate the decrease in the postprandiol rise in blood glucose [15].The 
blood glucose profile of the rats was determined at 30, 60, 90 and 120 min after extract/vehicle administration with a glucometer. Food but not water was withheld from the cages during the course of experimentation [15].

\section{Statistical analysis}

Data were analyzed using Student's t-test. Hyperlipidemia groups were compared with control and extract-treated groups. In the other experiments, the extract groups were compared with the reference group. Similarly, the generation of oxygen-free radicals with different solvent fractions was compared with that of the unfractionated extract. Quantitative glucose tolerance of each animal was calculated by trapezoid method using Prism software. (version 3, GraphPad software, Inc). $\quad P<0.05$ was used to determine significant difference.

\section{RESULTS}

The yield of the various fractions was as follows: petroleum ether $(0.052 \%)$, ether (0.115\%), chloroform (0.970 g, $0.092 \%)$, chloroform:methanol $(4: 1,0.083 \%)$, and chloroform:methanol (3:2, $0.068 \%)$.

\section{Key phytochemical constituents of extracts/fractions}

The extracts/fractions were positive for carbohydrates and/or glycosides, flavonoids, and sterols and/or terpenes. The petroleum ether, ether and chloroform fractions gave positive indication for Libermann Burchardt test (for steroids and/or terpenes) [16], liquid ammonia, $\mathrm{NaOH}$ and Shinoda test (for flavones) [17,18], Feigl test (for normal sugars) [19], and vanillin perchloric acid test (for 2-deoxy and 6-deoxy sugars) [20], indicating the presence of flavones/sterols/ terpenes in free state or in the form of their glycosides. However, chloroform-methanol (4:1) and chloroform-methanol (3:2) fractions were positive for Feigl, vanillin perchloric acid and $\mathrm{NaOH}$ tests, indicating the possible presence of phenols in the free state or as their glycosides.

\section{Effect of extracts/fractions on lipid profile of rats}

Table 1 shows that administration of triton WR-1339 caused a marked increase in the plasma levels of Tc (2.19-fold), Tg (2.66 fold), PI (2.66-fold), and protein (1.79-fold) but a decrease in PHLA (by $32 \%$ ).

Varying but significant decrease in lipid levels was noticed following treatment of hyperlipidemic rats with the extracts/fractions of $A$. violaceae flowers at an oral dose of 100 $\mathrm{mg} / \mathrm{kg}$. Ether and chloroform fractions decreased the levels of Tc, Tg, PI, and protein by $24,23,23,22 \%$ and $24,22,23$, $19 \%$, respectively, while petroleum ether, chloroform: methanol (4:1) and chloroform: methanol (3:2) fractions showed mild lipidlowering activity as compared to triton. On the other hand, the standard drug (gemfibrozil), at the same dose $(100 \mathrm{mg} / \mathrm{kg})$ decreased the plasma levels of $\mathrm{Tc}, \mathrm{Tg}, \mathrm{PI}$, and protein by $36,32,34$, and $27 \%$, respectively. Post-heparin lipolytic activity was partially activated in the plasma of the hyperlipidemic rats, producing a significant inhibition of $26 \%$. However, gemfibrozil caused a significant reversal of cholesterol acyltransferase activity (LCAT) and postheparin lipase activities (PHLA) as Table 1 shows.

In the high-fat diet (HFD) model (Table 2), feeding the rats with high-fat diet once a day for 30 days produced hyperlipidemia as evidenced by increase in the plasma levels of Tc (3.55 fold), TG (2.44-fold), PI (2.86-fold). The ether and chloroform extracts showed potent lipid-lowering activity, decreasing Tc, Tg, PI and protein by $25,26,27,23 \%$, and $23,22,21,22 \%$, respectively.

Table 3 shows that in HFD rats, there was increase in hepatic lipids as follows: Tc (1.88fold), Tg (1.46-fold), PI (1.65-fold), respectively. Ether and chloroform extracts 
Table 1: Lipid lowering activity of extracts fractions of $A$. violacea flowers in triton-treated hyperlipidemic rats (mean \pm standard deviation, $\mathrm{n}=6$ ). (Note: Change $(\%)$ in lipid lowering activity is shown in parenthesis)

\begin{tabular}{|c|c|c|c|c|c|}
\hline $\begin{array}{l}\text { Treatment } \\
\text { (Tc) }\end{array}$ & $\begin{array}{c}\text { Total Cholestero } \\
(\mathrm{Tg})\end{array}$ & $\begin{array}{c}\text { ol }^{\mathrm{a}} \text { Triglyceride }^{\mathrm{a}} \\
\text { (PI) }\end{array}$ & Phospholipid & Protein $^{b}$ & PHLA $^{c}$ \\
\hline Control & $94.18 \pm 7.21$ & $95.59 \pm 7.11$ & $84.34 \pm 6.82$ & $06.72 \pm 0.04$ & $16.66 \pm 1.14$ \\
\hline Triton treated & $\begin{array}{c}206.88 \pm 17.33 \\
(+2.19 \mathrm{~F})^{\text {t.x }}\end{array}$ & $\begin{array}{l}255.15 \pm 18.92 \\
(+2.66 \mathrm{~F})^{\text {t.*t }}\end{array}$ & $\begin{array}{l}225.16 \pm 20.00 \\
(+2.66 \mathrm{~F})^{*+* t}\end{array}$ & $\begin{array}{l}12.06 \pm 1.03 \\
(+1.79 \mathrm{~F})^{* x+*}\end{array}$ & $\begin{array}{l}11.31 \pm 0.80 \\
(-32)^{x+2}\end{array}$ \\
\hline $\begin{array}{l}\text { Triton+aqueous } \\
\text { extract }\end{array}$ & $\begin{array}{c}156.17 \pm 10.88 \\
(-24)^{\star \star * * 1}\end{array}$ & $\begin{array}{l}195.48 \pm 14.82 \\
(-23)^{* * \pm}\end{array}$ & $\begin{array}{l}175.25 \pm 13.00 \\
(-22)^{*}\end{array}$ & $\begin{array}{l}9.53 \pm 0.69 \\
(-21)^{* *}\end{array}$ & $\begin{array}{l}13.91 \pm 1.10 \\
(+19)^{* *}\end{array}$ \\
\hline $\begin{array}{l}\text { Triton + Pet- } \\
\text { Ether extract }\end{array}$ & $\begin{array}{c}189.96 \pm 13.84 \\
(-8)^{\mathrm{NS}}\end{array}$ & $\begin{array}{l}231.60 \pm 19.92 \\
(-9)^{\mathrm{NS}}\end{array}$ & $\begin{array}{c}214.91 \pm 20.00 \\
(-4)^{\mathrm{NS}}\end{array}$ & $\begin{array}{c}11.06 \pm 0.82 \\
(-8)^{\mathrm{NS}}\end{array}$ & $\begin{array}{l}12.08 \pm 2.90 \\
(+7)^{\mathrm{NS}}\end{array}$ \\
\hline Triton + Ether & $\begin{array}{l}157.98 \pm 12.80 \\
(-24)\end{array}$ & $\begin{array}{l}196.05 \pm 16.00 \\
(-23)^{* x+}\end{array}$ & $\begin{array}{l}173.76 \pm 12.88 \\
(-23)\end{array}$ & $\begin{array}{l}9.33 \pm 0.62 \\
(-22)^{* \pm}\end{array}$ & $\begin{array}{l}14.66 \pm 0.79 \\
(+23)^{* * *}\end{array}$ \\
\hline Triton $+\mathrm{CHCl}_{3}$ & $\begin{array}{c}160.08 \pm 12.06 \\
(-24)^{ \pm+*+2}\end{array}$ & $\begin{array}{l}200.00 \pm 14.84 \\
(-22)^{* * \pm+}\end{array}$ & $\begin{array}{l}165.03 \pm 13.44 \\
(-23)^{* * *}\end{array}$ & $\begin{array}{l}9.80 \pm 0.72 \\
(-19)^{* *}\end{array}$ & $\begin{array}{l}14.12 \pm 1.10 \\
(+20)^{* *}\end{array}$ \\
\hline $\begin{array}{l}\text { Triton }+ \\
\mathrm{CHCl}_{3}: \mathrm{MeOH} \\
(4: 1)\end{array}$ & $\begin{array}{l}186.20 \pm 14.44 \\
(-10)^{*}\end{array}$ & $\begin{array}{l}230.11 \pm 18.27 \\
(-10)^{*}\end{array}$ & $\begin{array}{l}193.76 \pm 15.72 \\
(-14)^{*}\end{array}$ & $\begin{array}{l}11.00 \pm 1.00 \\
(-09)^{\mathrm{NS}}\end{array}$ & $\begin{array}{l}12.00 \pm 0.38 \\
(+6)^{N S}\end{array}$ \\
\hline $\begin{array}{l}\text { Triton }+ \\
\mathrm{CHCl}_{3}: \mathrm{MeOH} \\
(3: 2)\end{array}$ & $\begin{array}{l}172.10 \pm 15.30 \\
(-17)\end{array}$ & $\begin{array}{l}202.14 \pm 14.87 \\
(-20)^{*+}\end{array}$ & $\begin{array}{l}181.40 \pm 16.00 \\
(-19)\end{array}$ & $\begin{array}{l}10.31 \pm 1.00 \\
(-14)^{*}\end{array}$ & $\begin{array}{c}13.50 \pm 0.77 \\
(+16)^{*}\end{array}$ \\
\hline $\begin{array}{l}\text { Triton+ } \\
\text { Gemfibrozil } \\
\quad \text { (standard drug }\end{array}$ & $\begin{array}{l}131.44 \pm 13.77 \\
(36)^{*+ \pm}\end{array}$ & $\begin{array}{l}174.16 \pm 15.00 \\
(32)^{1+x+1}\end{array}$ & $\begin{array}{l}148.40 \pm 13.12 \\
(-34)^{:+4}\end{array}$ & $\begin{array}{l}8.72 \pm 0.68 \\
(-27)^{x+2+}\end{array}$ & $\begin{array}{l}15.23 \pm 0.92 \\
(+26)^{* * *}\end{array}$ \\
\hline
\end{tabular}

Unit: ${ }^{a} \mathrm{mg} / \mathrm{dl},{ }^{\cdot} \mathrm{g} / \mathrm{dl},{ }^{\prime} \mathrm{nm}$ control. Triton + drug-treated groups compared with triton only; $F=$ fold; data are mean \pm standard deviation

Table 2: Lipid-lowering activity of extracts fractions of $A$. violacea flowers in hyperlipidemic rats (Note: Change (\%) in lipid lowering activity is shown in parenthesis)

\begin{tabular}{|c|c|c|c|c|}
\hline Treatment & $\begin{array}{c}\text { Total Cholesterol }^{\mathrm{a}} \\
\text { (Tc) }\end{array}$ & $\begin{array}{l}\text { Triglyceride }^{a} \\
\text { (Tg) }\end{array}$ & $\begin{array}{c}\text { Phospholipids }^{a} \\
\text { (PI) }\end{array}$ & Protein $^{\mathrm{b}}$ \\
\hline Control & $84.66 \pm 6.14$ & $87.17 \pm 6.32$ & $80.33 \pm 5.89$ & $06.70 \pm 0.08$ \\
\hline HFD only & $\begin{array}{c}300.87 \pm 20.77 \\
(+3.55 \mathrm{~F})^{* *+}\end{array}$ & $\begin{array}{c}212.88 \pm 17.11 \\
(+2.44 \mathrm{~F})^{+* *}\end{array}$ & $\begin{array}{l}230.00 \pm 14.84 \\
(+2.86 \mathrm{~F})^{1+* *}\end{array}$ & $\begin{array}{l}\begin{array}{l}12.11 . \pm 1.00 \\
(+1.80 \mathrm{~F})^{1+* *}\end{array}\end{array}$ \\
\hline $\begin{array}{l}\text { HFD + aqueous } \\
\text { extract }\end{array}$ & $\begin{array}{l}221.14 \pm 18.27 \\
(-26)^{*+*}\end{array}$ & $\begin{array}{l}160.33 \pm 12.00 \\
(-24)^{*+ \pm}\end{array}$ & $\begin{array}{l}170.32 \pm 13.00 \\
(-25)^{k+*+}\end{array}$ & ${ }^{9.50 \pm 0.37}$ \\
\hline $\begin{array}{l}\text { HFD+ Pet ether } \\
\text { extract }\end{array}$ & $\begin{array}{c}266.39 \pm 23.39 \\
(-11)^{\star}\end{array}$ & $\begin{array}{l}193.22 \pm 17.00 \\
(-9)^{\mathrm{NS}}\end{array}$ & $\begin{array}{l}210.64 \pm 17.09 \\
(-8)^{\text {NS }}\end{array}$ & $\begin{array}{l}11.11 \pm 1.00 \\
(-8)^{\mathrm{NS}}\end{array}$ \\
\hline $\begin{array}{l}\text { HFD + Ether } \\
\text { extract }\end{array}$ & $\begin{array}{c}225.51 \pm 19.82 \\
(-25)^{\star \pm \neq}\end{array}$ & $\begin{array}{l}157.33 \pm 12.88 \\
(-26)^{x+ \pm}\end{array}$ & $\begin{array}{l}167.30 \pm 12.77 \\
(-27)^{\star^{* *}}\end{array}$ & $\begin{array}{l}9.32 \pm 0.68 \\
(-23)^{*+ \pm \pm}\end{array}$ \\
\hline $\begin{array}{l}\mathrm{HFD}+\mathrm{CHCl}_{3} \\
\text { extract }\end{array}$ & $\begin{array}{l}230.14 \pm 20.84 \\
(-23)^{ \pm * t}\end{array}$ & $\begin{array}{l}165.66 \pm 14.72 \\
(-22)^{* *}\end{array}$ & $\begin{array}{l}180.21 \pm 13.37 \\
(-21)^{* *}\end{array}$ & $\begin{array}{l}9.40 \pm 0.82 \\
(-22)^{ \pm 0}\end{array}$ \\
\hline $\begin{array}{l}\mathrm{HFD}+\mathrm{CHCl}_{3}: \mathrm{CH}_{3} \mathrm{OH} \\
\text { (4:1) extract }\end{array}$ & $\begin{array}{c}260.00 \pm 18.77 \\
(-13)^{*}\end{array}$ & $\begin{array}{c}188.62 \pm 13.92 \\
(-11)^{*}\end{array}$ & $\begin{array}{c}204.66 \pm 16.77 \\
(-11)^{*}\end{array}$ & $\begin{array}{c}10.89 \pm 0.72 \\
(-10)^{*}\end{array}$ \\
\hline $\begin{array}{l}\mathrm{HFD}+\mathrm{CHCl}_{3}: \mathrm{CH}_{3} \mathrm{OH} \\
\text { (3:2)extract }\end{array}$ & $\begin{array}{c}248.62 \pm 20.43 \\
(-17)^{* *}\end{array}$ & $\begin{array}{c}190.44 \pm 14.00 \\
(-15)^{*}\end{array}$ & $\begin{array}{c}190.38 \pm 15.57 \\
(-17)^{* *}\end{array}$ & $\begin{array}{l}10.82 \pm 0.73 \\
(-11)^{*}\end{array}$ \\
\hline $\begin{array}{l}\text { HFD +Gemfibrozil } \\
\text { Standard drug }\end{array}$ & $\begin{array}{l}195.20 \pm 13.48 \\
(-35)^{* * * *}\end{array}$ & $\begin{array}{l}142.22 \pm 11.00 \\
(-33)^{* \pm}\end{array}$ & $\begin{array}{l}152.60 \pm 11.66 \\
(-34)^{* * *}\end{array}$ & $\begin{array}{l}8.48 \pm 0.32 \\
(-30)^{ \pm+x}\end{array}$ \\
\hline
\end{tabular}

Unit: ${ }^{a} \mathrm{mg} / \mathrm{dl} ;{ }^{\mathrm{b}} . \mathrm{g} / \mathrm{dl} .{ }^{*} p<0.05,{ }^{* *} p<0.01,{ }^{* * *} p<0.001,{ }^{\text {NS }}$ not significant; cholesterol-fed hyperlipidemic groups compared with control; F $=$ fold; data are mean \pm standard deviation 
Sethi et al

Table 3: Effect of fractions of $A$. violacea flowers on hepatic biochemical parameters in hyperlipidemic rats (Note: Change (\%) in in parameter values is shown in parenthesis)

\begin{tabular}{|c|c|c|c|c|}
\hline Parameter & $\begin{array}{l}\text { LPL } \\
\text { activity }\end{array}$ & $\begin{array}{c}\text { Total Cholesterol }^{\mathrm{a}} \\
\text { (Tc) }\end{array}$ & $\begin{array}{c}\text { Triglyceride }^{\mathrm{a}} \\
\text { (Tg) }\end{array}$ & $\begin{array}{l}\text { Phospholipids }^{\mathrm{a}} \\
\text { (PI) }\end{array}$ \\
\hline Control & $135.44 \pm 9.87$ & $7.00 \pm 0.17$ & $11.00 \pm 1.00$ & $23.00 \pm 1.72$ \\
\hline HFD only & $\begin{array}{l}73.37 \pm 4.80 \\
(-46)^{* \star \star}\end{array}$ & $\begin{array}{l}13.21 \pm 0.72 \\
(+1.88 \mathrm{~F})^{* \star *}\end{array}$ & $\begin{array}{l}16.12 \pm 0.82 \\
(+1.46 \mathrm{~F})^{* * \star}\end{array}$ & $\begin{array}{l}38.12 \pm 3.00 \\
(-1.65 \mathrm{~F})^{* \star \star}\end{array}$ \\
\hline $\begin{array}{l}\text { HFD + aqueous } \\
\text { extract }\end{array}$ & $\begin{array}{l}84.17 \pm 6.24 \\
(+13)^{*}\end{array}$ & $\begin{array}{l}10.00 \pm 0.68 \\
(-24)^{\star * \star}\end{array}$ & $\begin{array}{l}12.00 \pm 0.82 \\
(-25)^{* \star \star}\end{array}$ & $\begin{array}{l}29.12 \pm 2.20 \\
(-23)^{* * *}\end{array}$ \\
\hline $\begin{array}{l}\text { HFD + Pet ether } \\
\text { extract }\end{array}$ & $\begin{array}{l}75.53 \pm 3.89 \\
(+3)^{\star *}\end{array}$ & $\begin{array}{l}11.11 \pm 0.79 \\
(-16)^{*}\end{array}$ & $\begin{array}{l}15.10 \pm 1.00 \\
(-6) \mathrm{NS}\end{array}$ & $\begin{array}{l}30.77 \pm 2.18 \\
(-19)^{* *}\end{array}$ \\
\hline $\begin{array}{l}\text { HFD + ether } \\
\text { extract }\end{array}$ & $\begin{array}{l}84.39 \pm 7.31 \\
(+13)^{* \star \star}\end{array}$ & $\begin{array}{l}9.00 \pm 0.17 \\
(-26)^{* \star \star}\end{array}$ & $\begin{array}{l}12.00 \pm 0.62 \\
(-25)^{* * \star}\end{array}$ & $\begin{array}{l}28.11 \pm 0.41 \\
(-26)^{* \star \star}\end{array}$ \\
\hline $\begin{array}{l}\mathrm{HFD}+\mathrm{CHCl}_{3} \\
\text { extract }\end{array}$ & $\begin{array}{c}85.27 \pm 6.00 \\
(+14)^{*}\end{array}$ & $\begin{array}{c}10.77 \pm 0.66 \\
(-18)^{*}\end{array}$ & $\begin{array}{c}13.00 \pm 0.77 \\
(-19)^{*}\end{array}$ & $\begin{array}{l}30.2 .21 \pm 3.00 \\
(-20)^{* *}\end{array}$ \\
\hline $\begin{array}{l}\mathrm{HFD}+\mathrm{CHCl}_{3}: \mathrm{CH}_{3} \mathrm{OH} \\
(4: 1) \text { extract }\end{array}$ & $\begin{array}{c}76.62 \pm 5.84 \\
(+4)\end{array}$ & $\begin{array}{c}11.90 \pm 0.69 \\
(-10)^{*}\end{array}$ & $\begin{array}{c}14.77 \pm 0.82 \\
(-8) \mathrm{NS}\end{array}$ & $\begin{array}{l}34.82 \pm 3.14 \\
(-9) \mathrm{NS}\end{array}$ \\
\hline $\begin{array}{l}\mathrm{HFD}+\mathrm{CHCl}_{3}: \mathrm{CH}_{3} \mathrm{OH} \\
\text { (3:2)extract }\end{array}$ & $\begin{array}{l}78.66 \pm 5.70 \\
(+6)\end{array}$ & $\begin{array}{c}10.60 \pm 0.37 \\
(-19)^{* *}\end{array}$ & $\begin{array}{c}14.00 \pm 0.6 \\
(-13)^{*}\end{array}$ & $\begin{array}{l}30.12 \pm 2.10 \\
(-20)^{* *}\end{array}$ \\
\hline $\begin{array}{l}\text { HFD + Gemfibrozil } \\
\text { standard drug }\end{array}$ & $\begin{array}{c}88.82 \pm 6.39 \\
(+17)^{*}\end{array}$ & $\begin{array}{c}8.50 \pm 0.28 \\
(-35)^{* * *}\end{array}$ & $\begin{array}{l}11.50 \pm 1.00 \\
(-28)^{* \star \star}\end{array}$ & $\begin{array}{l}24.04 \pm 0.72 \\
(-37)^{\star \star \star}\end{array}$ \\
\hline
\end{tabular}

lowered Tc, Tg and, PI by 26, 25, $26 \%$, and $18,19,20 \%$, respectively. The antioxidant activities of the extracts/fractions are shown in Table 4. There was significant inhibition of superoxide anions by (7 - $32 \%)$, hydroxyl radicals $(15-36 \%)$ and microsomal lipid peroxidation (13 - $35 \%)$ in non-enzymatic system compared to that of extracts.

Table 5 presents the antihyperglycaemic activity of the extract/fractions based on the sucrose-loaded rat model. It is evident from the results that $18.2,13.5,13.9 \%(p<0.05)$, $25.2 \%(p<0.05) \quad 21.6 \%(p<0.05)$ and $23.2 \%(p<0.05)$ reduction in glucose area under curve (AUC) was achieved by 100 $\mathrm{mg} / \mathrm{kg}$ dose of aqueous, petroleum ether, ether, chloroform, chloroform-methanol (4:1) and chloroform-methanol (3:2) extracts/ fractions. By comparison, the reference standard drug glybenclamide $(25 \mathrm{mg} / \mathrm{kg})$, caused a reduction of $33.2 \%(p<0.01)$ in hyperglycaemia.

\section{DISCUSSION}

Triton WR-1339 acts as a surfactant, suppresses the action of lipases and blocks the uptake of lipoproteins by extrahepatic tissues, thus resulting in increase in the levels of circulatory lipids [7]. Furthermore, triton WR-1339 is known to cause structural modifications in circulatory lipoproteins, which hinder their interaction with capillary lipoprotein lipases [21]. It is probable that the 
extracts/fractions may have interfered with clustering lipoproteins coated with triton [21]. Table 4: Effect of extracts fractions of $A$. violacea flowers on generation of free radical and lipid peroxidation in rat liver microsomes in vitro (Note: Change (\%) in antioxidant activity is shown in parenthesis)

\begin{tabular}{|c|c|c|c|c|}
\hline Treatment & $\begin{array}{l}\text { Conc } \\
(\mu \mathrm{g} / \mathrm{ml})\end{array}$ & $\begin{array}{c}\text { Formation of } \\
\text { Superoxide anions }\end{array}$ & $\begin{array}{c}\text { Formation of } \\
\text { hydroxyl radicals }\end{array}$ & $\begin{array}{l}\text { Microsomal lipid } \\
\text { peroxidation }^{c}\end{array}$ \\
\hline Aqueous & $\begin{array}{l}100 \\
200\end{array}$ & $\begin{array}{l}\text { Control } 173.72 \pm 13.70 \\
\text { Exp } 151.38 \pm 12.00(-13)^{*} \\
\text { Exp 133.47 } 111.00(-23)^{* *}\end{array}$ & $\begin{array}{l}\text { Control } 100.12 \pm 7.80 \\
\text { Exp } 84.87 \pm 6.00(-15)^{\star} \\
\text { Exp } 75.66 \pm 5.77(-25)^{\star * *}\end{array}$ & $\begin{array}{c}\text { Control } 82.94 \pm 7.00 \\
\operatorname{Exp} 75.88 \pm 5.38(-8)^{\mathrm{NS}} \\
\operatorname{Exp} 70.00 \pm 6.00(-16)^{*}\end{array}$ \\
\hline Pet ether & $\begin{array}{l}100 \\
200\end{array}$ & $\begin{array}{l}\text { Control } 167.93 \pm 14.14 \\
\text { Exp } 156.06 \pm 12.22(-7)^{\mathrm{NS}} \\
\text { Exp } 144.46 \pm 11.92(-13)^{*}\end{array}$ & $\begin{array}{l}\text { Control } 114.71 \pm 8.39 \\
\text { Exp } 101.66 \pm 8.00(-11)^{*} \\
\text { Exp } 93.29 \pm 6.80(-18)^{* *}\end{array}$ & 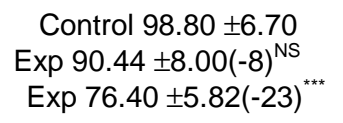 \\
\hline Ether & $\begin{array}{l}100 \\
200\end{array}$ & $\begin{array}{l}\text { Control } 169.92 \pm 13.32 \\
\text { Exp } 130.30 \pm 10.88(-23)^{* * *} \\
\text { Exp } 114.88 \pm 8.88(-32)^{* * *}\end{array}$ & $\begin{array}{l}\text { Control } 110.22 \pm 7.79 \\
\text { Exp } 80.19 \pm 6.90(-27)^{\star \star \star} \\
\operatorname{Exp} 70.50 \pm 5.70(-36)^{* * \star}\end{array}$ & $\begin{array}{l}\text { Control } 100.39 \pm 8.24 \\
\text { Exp } 80.11 \pm 6.37(-20)^{* *} \\
\operatorname{Exp} 65.22 \pm 4.00(-35)^{* * *}\end{array}$ \\
\hline $\mathrm{CHCl}_{3}$ & $\begin{array}{l}100 \\
200\end{array}$ & $\begin{array}{l}\text { Control } 168.15 \pm 12.66 \\
\text { Exp } 132.66 \pm 11.00(-21)^{* *} \\
\text { Exp 120.27 } \pm 9.88(-28)^{* * *}\end{array}$ & $\begin{array}{l}\text { Control } 129.81 \pm 11.11 \\
\text { Exp } 115.90 \pm 8.77(-11)^{*} \\
\text { Exp } 95.57 \pm 6.94(-26)^{* *}\end{array}$ & $\begin{array}{l}\text { Control } 96.40 \pm 8.00 \\
\text { Exp } 80.37 \pm 6.77(-17)^{*} \\
\operatorname{Exp} 70.22 \pm 5.33(-27)^{* * *}\end{array}$ \\
\hline $\begin{array}{l}\mathrm{CHCl}_{3}: \mathrm{MeOH} \\
(4: 1)\end{array}$ & $\begin{array}{l}100 \\
200\end{array}$ & $\begin{array}{l}\text { Control } 152.76 \pm 12.70 \\
\text { Exp } 136.00 \pm 9.84(-11)^{*} \\
\text { Exp } 126.33 \pm 10.82(-17)^{* *}\end{array}$ & $\begin{array}{l}\text { Control } 124.78 \pm 10.11 \\
\text { Exp } 115.57 \pm 9.66(-7)^{\mathrm{NS}} \\
\text { Exp } 105.85 \pm 6.94(-15)^{*}\end{array}$ & $\begin{array}{l}\text { Control } 102.30 \pm 8.11 \\
\text { Exp } 88.77 \pm 6.11(-13)^{*} \\
\text { Exp } 78.44 \pm 5.33(-23)^{* * *}\end{array}$ \\
\hline $\begin{array}{l}\mathrm{CHCl}_{3}: \mathrm{MeOH} \\
(3: 2)\end{array}$ & $\begin{array}{l}100 \\
200\end{array}$ & $\begin{array}{l}\text { Control } 170.89 \pm 13.90 \\
\text { Exp } 157.03 \pm 11.78(-8)^{\mathrm{NS}} \\
\operatorname{Exp} 148.58 \pm 10.44(-13)^{*}\end{array}$ & $\begin{array}{l}\text { Control } 113.06 \pm 9.84 \\
\text { Exp } 90.13 \pm 7.80(-20)^{* *} \\
\quad \operatorname{Exp} 88.66 \pm 4.17(-21)^{* *}\end{array}$ & $\begin{array}{l}\text { Control } 89.34 \pm 7.11 \\
\text { Exp } 83.38 \pm 6.24(-7)^{\mathrm{NS}} \\
\operatorname{Exp} 77.70 \pm 5.37(-13)^{*}\end{array}$ \\
\hline Standard drug & & $\begin{array}{l}\text { Control } 90.38 \pm 7.12 \\
\text { Exp } 20.50 \pm 1.66(-77)^{* * *} \\
\text { (Alloperinol) }\end{array}$ & $\begin{array}{c}\text { Control } 75.22 \pm 5.87 \\
\text { Exp } 41.30 \pm 1.75(-45)^{* * *} \\
\text { (Mannitol) }\end{array}$ & $\begin{array}{c}\text { Control } 88.37 \pm 9.14 \\
\text { Exp } 41.83 \pm 3.14(-53)^{* * *} \\
(\alpha \text {-tocopherol })\end{array}$ \\
\hline
\end{tabular}

Units: ${ }^{a}$ nmol formazone formed/min; ${ }^{b} n$ mole MDA/h; ${ }^{*} p<0.05,{ }^{* *} p<0.01,{ }^{* * *} p<0.001,{ }^{N S}$ not significant; reference (standard drug) compared to systems without drug treatment; Exp = extract-treated; data are mean \pm standard deviation

Table 5: Antihyperglycaemic activity (mean \pm SEM) of the extracts/fractions of $A$. violacea flowers in sucrose-loaded rat model

\begin{tabular}{|c|c|}
\hline Extract/fraction & Antihyperglycaemic \\
\hline & activity $\mathrm{AUC}_{0-120 \mathrm{~min}}$ \\
\hline Control & $14270 \pm 451.0$ \\
\hline Aqueous extract $^{a}$ & $11680 \pm 194(-18.2)^{*}$ \\
\hline Pet ether extract ${ }^{a}$ & $12340 \pm 304(-13.5)$ \\
\hline Ether extract $^{\mathrm{a}}$ & $12280 \pm 286 .(-13.9)$ \\
\hline Chloroform extract $^{a}$ & $10670 \pm 185(-25.2)^{*}$ \\
\hline $\begin{array}{l}\text { Chloroform-methanol } \\
(4: 1) \text { extract }^{\mathrm{a}}\end{array}$ & $11200 \pm 340(-21.5)^{\star}$ \\
\hline $\begin{array}{l}\text { Chloroform-methanol } \\
(3: 2) \text { extract }^{\mathrm{a}}\end{array}$ & $10960 \pm 307(-23.2)^{*}$ \\
\hline Glybenclamide $^{b}$ & $9526 \pm 313.0(-33.2)^{\star *}$ \\
\hline
\end{tabular}

${ }^{*} p<0.05,{ }^{* *} p<0.01 ;{ }^{a} 100 \mathrm{mg} / \mathrm{kg}$ dose; ${ }^{b} 25 \mathrm{mg} / \mathrm{kg}$ dose. Note: AUC was based on fasting blood glucose levels; data are mean \pm standard deviation

In this way, lipoprotein become freely catabolized by these enzymes.

Stimulation of plasma lecithin-cholesterol acyltransferase (LCAT) and hepatic lipases is the mechanism responsible for a significant lowering of $\beta$-lipoprotein lipid. Though the ether and chloroform extracts caused significant decrease in the plasma levels of lipids in triton as well as HFD models of hyperlipidemia, their effects were comparatively less than that of the standard drug, gemfibrozil.

Trop J Pharm Res, April 2012;11 (2):232 
Hyperlipidemia may also induce other abnormalities such as oxidation of fatty acids, leading to the formation of ketonic bodies as well as liver and muscle resistance to insulin, which initiates the progression of diabetes in patients [7]. The effect of these extracts/fractions on triglyceride lowering was also observed through reversal of postheparin treated animals. There is a significant correlation between the ability of tissue to incorporate free fatty acid by hydrolysis of lipoprotein triacylglycerol and the enzyme, lipoprotein lipase [22]. The extracts/fractions inhibited cholesterol biosynthesis and potentiated the activity of lipolytic enzymes to early clearance of lipids from circulation in triton-induced hyperlipidemia. The data obtained indicate restoration of PHLA activity following treatment with the extracts/fractions. Furthermore, due to increase in hyperglycemia, non-enzymic glycosylation occurred, accompanied by glucose oxidation. These reactions, being catalyzed by $\mathrm{Cu}_{2}{ }^{+}$and $\mathrm{Fe}_{2}{ }^{+}$, resulted in the formation of $\mathrm{O}_{2}{ }^{-}$and $\mathrm{OH}$ radicals, which further accelerates the risk of cardiac diseases in dyslipidemic patients [23]. The extracts/fractions evaluated in this study may inhibit oxidative modification of LDL and thus accelerate the turnover of LDLcholesterol in liver [24].

The involvement of hydroxyl free radical $(\mathrm{OH})$ has been found to be a major causative factor for peroxidative damage to lipoproteins and this is responsible for inhibition and progression of atherosclerosis in hyperlipidemic subjects [5]. The potentially reactive derivatives of oxygen, known as reactive oxygen species (ROS), such as superoxide radical, hydroxyl radical and hydrogen peroxide are continuously generated inside the human body as a consequence of exposure to exogenous chemicals and/or a number of endogenous metabolic processes involving redox enzymes and bioenergetics electron transfer [25]. The antioxidant and free oxygen radical scavenging activities of the extracts/fractions appear to be mediated through metal ion chelators and xanthine oxidase inhibitors [26].

Antihyperglycaemic activity in sucrose-loaded normoglycemic rat model is usually due to insulin secreteceous, insulin sensitizing, insulin mimetic activities, etc. The extracts/fractions probably have insulin secreteceous activity as its activity compares with that of glybenclamide, which is insulin secretaceous [27].

A drug with multi-fold activity that includes antioxidant, antidiabetic and lipid lowering effects such as demonstrated by the extracts/fractions should potentially be in great demand.

\section{CONCLUSION}

Findings from this study suggest that the flowers of $A$. violacea flowers, in particular, the ether and chloroform fractions, have good potentials for lipid management. However, further investigations to isolate and identify antihyperlipidemic and antioxidant principles in the plant as well as elucidate its mode of action are required.

\section{ACKNOWLEDGEMENT}

The authors are thankful to CDRI, Lucknow, India for assistance with HPLC determinations. One of us (R.P) is thankful to the University Grants Commission, New Delhi, for financial assistance.

\section{REFERENCES}

1. Inove $T$, Hayashi $M$, Takayanagi $K$, Morooka $S$. Lipid lowering therapy with fluvastatin inhibits oxidation modifications of low density lipoprotein and improves vascular endothelial function in hypercholesterolemic patients. Atherosclerosis 2002; 160(2): 369-376.

2. Graham DJ, Staffa JA, Shatin D,.Andrade SE Schech SD, Lagrenade L, Gurwitz JH, Chan $K A$, Goodman MJ, Platt $R$. Incidence of Hospitalized Rhabdomyolysis in Patients Treated With Lipid-Lowering Drugs. JAMA 2004; 292(21): 2585-2590.

3. Evans $M$, Rees $A$. The Myotoxicity of Statins. Curr.Opin. Lipidol 2002; 13: 415-420.

Trop J Pharm Res, April 2012;11 (2):233 
4. Ravaglia G, Forti P, Maioli F, Bastagli F, Chiappelp $M$, Molesi $F$, Solandi L, Patterson C. Metabolic syndrome: prevalence and prediction of mortality in elderly Individuals. Diabetes Care 2006; 29(11): 2471-2476.

5 Parthasarathy S, Steinberg D, Witztum JL. The role of oxidized low density lipoprotein with pathogenesis of atherosclerosis. Annu Rev Med 1992; 43: 219-225.

6. Chander R, Khanna AK, Mathur SK, Kar A, Rastogi AK. Antidyslipidemic and Antioxidant activities of SBC: A herbal preparation. Ethanobotany 2002; 14: 123-128.

7. Sethi A, Maurya A, Pandey AK, S, Bhatia G, Khan MM, Khanna AK, Bishnoi A. Expedient synthesis of some novel pregnanes derivatives and their evaluation as anti-oxidant and antidyslipidemic agent. Med Chem Res 2011; 20(1): 36-46.

8. Sethi A, Srivastava S, Bhatia A, Bhatia G, Khanna AK, Saxena JK. Pregnane glycoside from Hemidesmus indicus as potential anti-oxidant and anti-dyslipidemic Agent. Natural Product Research 2010; 24(15): 1371-1378.

9. Bhattacharya J, Morais MSQ. 5,6-dimethoxy-7hydroxycourmarin (unckalin) from $A$. blanchetti, isolation and ${ }^{13} \mathrm{C} \quad N M R$ characteristic. J NatProd 1986; 49(2): 354-355.

10. Schmidt N De F, Yunes RA, Schaab EH, Malheiros $A$, Cechinel V, Franchi GC Jr, Nowill $A E$, Cardoso $A A$, Yunes JA. Evaluation of the antiproliferative the effect the extract of $A$. blanchetti and A.schottii on the growth of leukemic and endothelial cells. J Pharm Pharm Sci 2006; 9(2): 200-208.

11. Sethi A, Deepak D, Khare MP, Khare A. A Novel Pregnane glycoside from Periploca Calophylla. J Nat Prod 1988; 51(4): 787-790.

12. Bloor SJ. Overview of methods of analysis and identification of flavonoids. Methods in Enzymology 2001; 335: 3-14.

13. Venkatesh B, Tan CH, Kiene DE, Lam TJ.Steroid metabolism in teleost gonads purification and identification of metabolities by High Performance Liquid Chromatography. Steroids 1992; 57 (6): 276-281.

14. Sethi A, Maurya A, Tiwari V, Srivastava S, Shaheen F, Bhatia G, Khan MM, Khanna AK, Saxena $J K$. Expeditious and convenient synthesis of pregnanes and its glycosides as potential antidyslipidemic anti-oxidant agents. Biorg. Med.Chem 2007; 15: 4520-4527.

15. Kumar $A$, Sharma $S$, Tripathi VD, Maurya RA, Srivastav SP,Bhatia G, Tamrakar AK, Srivastava AK. Design and synthesis of 2,4disubstituted polyhydroquinolines as prospective antihyperglycemic and lipid modulating agents. Biorg.Med.Chem 2010; 18(11): 4138-4148.

16. Abisch E, Reichstein T. Orientierende chemische Untersuchung einiger apocynaceen. Helv.Chim.Acta 1960; 43(6): 1844-1861.

17. Harborne JB. Phytochemical Methods. Madras: $3^{\text {rd }}$ Ed. Chapman and Hall; 1999; pp 60-66.

18. Onwukaeme DN,.lkuegbvweha TB, Asonye CC. Evaluation and Phytochemical constituents, Antibacterial acitivities and Effects of Exudate of Pycanthus Angolensis

Weld Warb (Myristicaceae) on Corneal Ulcers in Rabbits. Trop J Pharm Res 2007; 6(2): 725 730.

19. Prakash K, Deepak D, Khare A, Khare MP. A pregnane glycoside from Streblus asper. Phytochemistry 1992; 31(3): 1056-1057

20. Maclennan AP, Randall HM, Smith DW. Detection and identification of deoxy sugars on paper chromatograms. Anal Chem 1959; 31(12): 2020-2022.

21. Schotz MC, Scanu A, Page IH. Effect of Triton on Lipoprotein lipase of rat plasma. Am. J. Physiol, 1957, 188,399-402

22. Wing DR, Robinson DF. Clearing-factor lipase in adipose tissue. A possible role of adenosine 3', 5'(cyclic)-monophosphate in the regulation of its activity. Biochem J 1968; 109: 841-89.

23. Asahina $T$, Kashiwagi A, Nish OY. Impaired activation of glucose oxidation and NADPH supply in human endothelial cells exposed to $\mathrm{H}_{2} \mathrm{O}_{2}$ in high glucose medium. Diabetes 1995; 44: 520-526.

24. Windler EET, Kovanen PT, Chaoyu S, Brown MS, Havel RJ, Goldstein JL. The estradiolstimulated lipoprotein receptor of rat liver. $A$ binding site that membrane mediates the uptake of rat lipoproteins containing apoproteins B and E. J Biol Chem 1980; 255(21): 10464-10471.

25. Rajani GP, Ashok P. In vitro antioxidant and antihyperlipidemic activities of Bauhinia Variegata Linn. Ind J Pharmacol 2009; 41(5): 227-232.

26. Geethaa Sahgal, Surash Ramanathan, Sreenivasan Sasidharan, Mohd Nizam Mordi, Sabariah Ismail and Sharif Mahsufi Mansor. In vitro antioxidant and xanthine oxidase inhibitory activities of methanolic swietenia mahagoni seed extracts. Molecules 2009; 14(11): 44764485.

27. Bhatia G, Rizvi F, Saxena R, Puri A, Khanna AK, Chander R, Rastogi AK. In vivo model for dyslipidemic with diabetes mellitus in hamster. Ind J Exp Biol 2003; 41: 1456-1460. 